\title{
MULTICULTURAL ART EDUCATION PROFESSIONAL DEVELOPMENT: WHAT AN AMERICAN TEACHER LEARNED FROM NEW ZEALAND ART EDUCATORS AND ARTISTS
}

Courtnee Bennett

I am a visual arts secondary school teacher from Albuquerque, New Mexico, who received a Fulbright Distinguished Awards in Teaching grant to conduct art education research in New Zealand. In this comparative case study, I write about my observations of the two countries.

Manzano High School, where I teach, has a very diverse student population. I feel I cannot teach in-depth lessons about all the different cultures of my students, due to time constraints and mandated state standards. Therefore, I tend to create what I now understand as superficial cultural activities, like making sugar skulls for the Day of the Dead to include Mexican culture. A couple years ago, a student expressed boredom and frustration over creating sugar skulls because he made them every year in art classes and this activity fails to explore actual Mexican culture.

This experience made me realise that I needed to learn how to teach multicultural perspectives that honour students and promote learning.' I want my students to feel that their heritage is respected and appreciated, and everyone to become knowledgeable about all the different cultures represented in our class. Moreover, exposing my students to a variety of cultural artwork makes them more tolerant, empathetic and accepting of differences they find in the broader world. ${ }^{2}$

In order to deepen and extend my teaching skills and knowledge and move beyond superficial cultural activities to more sophisticated, nuanced and less stereotypical representations, I needed more meaningful professional development experiences aimed at exploring how to engage students from a variety of cultures in one classroom. Additionally, I wanted to learn how to support the students in my classes who want to become professional artists. Learning how artists retain and explore their culture in a commercial setting will help me figure out the guiding principles I need to instill in my students so they can continue reflecting upon their culture and how and where they fit into the complicated world we live in.

The only pathway I currently know of is to attend university - but the university track does not support practitioners in art fields such as muralists or street artists, tattoo artists, welders, and many more. Therefore, the two questions I sought to answer as an educator were:

How can art educators create engaging, meaningful lessons that center on multicultural perspectives and culturally sustaining pedagogy?

What support do professional artists receive on their pathway to become established, practising artists?

To discover the answers to these questions, I needed to see this inquiry in a new context, which led me to look outside of the American education system. The Fulbright Distinguished Awards in Teaching grant offers professional 
development research in numerous countries around the world. I discovered that the United States and New Zealand had similar beginnings to their education systems, but that New Zealand had approached diversity differently in more recent years.

Both countries' art education programs developed from economically relevant technical drawing classes drawn from Britain's education system. Both countries shifted to student-centered approaches that focused on art for creative purposes and supported child development. ${ }^{3}$ The Treaty of Waitangi ( 1840$)$ created the foundation for the inclusion of Mãori culture in the New Zealand education system. Therefore New Zealand's art curriculum included Māori arts and crafts before focusing on Māori culture, beliefs and ethnic perspectives. ${ }^{4} \mathrm{New}$ Zealand's education vision stresses the importance of having a strong sense of national and cultural identity. According to the New Zealand Education Curriculum, "The curriculum reflects New Zealand's cultural diversity and values the histories and traditions of all its people." Cultural diversity is one of eight principles that schools use when making decisions. ${ }^{5}$

On the other hand, American art education's short-lived emphasis on multicultural concepts was unclear and took place in response to the dominance of White culture rather than developing a full understanding of the different heritages in the nation and their societal views. ${ }^{6}$ I feel as a teacher, and also as a student who went through the American education system, that the United States has so many ethnicities and cultures that it would be unfair to single one out and only teach a Westernised view of education. At the moment, we are basically ignoring all the other cultures except for the White Eurocentric dominant culture.

This trend of White dominance is evident throughout the American education system. In the United States, education policies and regulations are the responsibilities of each state. Each school is part of a district - an educational body governing many schools in a large geographical area that is managed by a single superintendent, his/her personnel, and the elected officials of the school board. Although school board members are supposed to reflect the diversity within the local community, according to GreatSchools investigators who surveyed 44 American school boards, approximately 70 percent of the members are White. The Albuquerque Public Schools district where I work includes a wide range of racially, ethnically and culturally diverse students, but the seven members of the school board are White and Hispanic. At Manzano High School, the student population is 48 percent Hispanic/ Latino, 34 percent Caucasian (White), 6 percent Native American (Indigenous), 6 percent Asian and/or Pacific Islander, and 6 percent Black and African American. ${ }^{8}$ Within the indigenous communities, there are multiple tribes and pueblos (permanent towns) with different languages, traditions and customs. Yet the White and Hispanic school board members ultimately influence educational content insofar as they hire the superintendent who runs the district and coordinates the student learning and teaching best-practices with the schools' principals.

American schools tend to operate hierarchically, with decisions about professional development made by district personnel in which teachers are mandated to participate. At Manzano High School, our principals choose specific teachers to create workshop sessions that all teachers attend, but the school itself has very little autonomy over the content presented. As an art educator, I have found that many of these workshops are not relevant as they involve core subjects such as reading, writing, social studies, math, and science, or classroom management styles geared for classes where students listen to the teachers teach and then quietly work from a textbook, or work in small groups for short periods. Art classes are much less structured, as students move around the classroom to source supplies, create individually inspired artwork and talk with their classmates while creating art.

Thus it is difficult to tailor mainstreamed professional development workshops to the different ethnic and cultural student populations attending the schools in my region. Manzano High School is one of the most diverse high schools in the Albuquerque Public Schools district, and when I asked my students last Fall what cultures they identified with, they mentioned a total of 27 different cultures. These included: American; New Mexican; Hispanic, both from Spain and Central America; Native American, from tribes and pueblos such as Apache, Zuni, Navajo, Hopi and Santa Domingo; European cultures including French, Dutch, Italian, German, Irish and Serbian; Mexican and Mexican American; Southern; Arabian; Asian cultures such as Chinese, Filipino and Vietnamese; Catholic; Black, African, and African-American; Cuban; and White and Caucasian. 
When I asked if the students felt their culture was respected at school, some said 'yes' and some said 'no,' but many could not articulate why they felt that way. Those that could specified that people respected and liked cultural foods, such as burritos and green chile; some home languages, such as Spanish and Navajo, were taught at school; and there were some activities for Native Americans, such as the extracurricular Indigenous Club. One student said that minority stereotypes still existed and were foisted on them. Many students replied that culture is not discussed at school - which to me signifies that non-White culture is repressed in the American, Westernised education system. At my school, I feel that we hardly include or celebrate the vast diversity of our cultures, except during our multicultural assembly where students perform cultural songs and dances.

Is culture repressed because of the racial and cultural demographics of American teachers? I do not believe this is a major contributing factor to cultural repression in United States. It is true that most American teachers are White and have succeeded in the Western education system, with 47 percent of them obtaining a Master's degree after the required Bachelor's degree. ${ }^{9}$ But New Zealand shares this characteristic, as most of their teachers are of European ethnicity. Dr jill Smith determined that in New Zealand schools race did not affect students' learning and lesson outcomes, but that the teacher's disposition was the main factor when embracing the students' ethnic and cultural diversity. ${ }^{10}$ Therefore, it is my teaching disposition that will reflect how my students embrace culture in my classroom. I am White and can effectively implement cultural competence in my classroom by learning how New Zealand teachers learn about their students' cultural perspectives, create lesson plans related to their heritage, and help students become proud of their ethnicities.

While in New Zealand, I spoke with art educators, teachers and artists and learned about Māori culture. One of the main concepts I observed is storytelling. Stories are everywhere, something which I do not feel is a primary focus in American education and the culture in general. In art education, stories were essential. Students in mainstream schools in Years 11, 12 and 13 create portfolios that center on a narrative that students explore all year long. Students choose an in-depth topic of great interest to them, whether it be their heritage or family background, an important relationship in their life, or a social or environmental issue such as climate change.The artists I interviewed specified that their artwork centered on narratives, and some stated that people bought their artwork because of the story it told. In the schools where I have taught, the art curriculum only has one class, Advance Placement Art, that explores a particular theme. The other classes allow students some freedom to choose the subject matter when teaching a technique. For example, when I teach facial proportions, students draw a self-portrait in charcoal. I take a photograph of them or they choose one of themselves that was taken previously as a selfie or by a friend. Sometimes the self-portrait reflects their personality, essentially telling the story of the student's character, but at other times it can be devoid of expression.

Another aspect I noticed in New Zealand is communal discussions involving decolonisation. For example, I attended the Barbarian Productions staging of Captain Cook Thinks Again, produced by Jo Randerson and performed by Tom Clarke, that aimed to educate people and reflect on the British colonisation of the country and how we can rectify the repressive past with more progressive thoughts, conversations and actions. This was done in a creative oral story format.

Not all the communal discussions I participated in were as creative as this one, but they were still implemented in institutional settings and at the personal level. At Victoria University in Wellington, students constructively critiqued their course and professor midway through the term. Students met during class and gave feedback about the course content and instruction and the elected class representatives discussed this with the professor, creating an open dialogue that benefited both parties and ideally improved the class. This type of communal discussion does not happen at either primary, secondary or tertiary level in the United States.

Oral history, storytelling and communal discussions are common aspects of many of the students' cultures at Manzano High School, and one of our current initiatives is to include students' families more in the school community. But our educational content does not include these cultural aspects - rather, it is dictated and mandated by people 
who are not part of and who do not understand our community. I believe that if we want more community involvement, we need to listen to what our community values and incorporate those things into the school environment and educational curriculum. One way I can start this process is to begin combining historical, traditional and contemporary attributes of neighbourhood cultures into the art education curriculum in my classroom.

I have observed the blending of traditional and modern elements throughout New Zealand culture in many different aspects of community life. During the Te Matatini Festival in Wellington, dances included the traditional kapa haka dance styles, but portrayed current, relevant topics affecting the iwi, such as one community's struggle with cancer.To welcome Māori participants to Wellington, seven street pedestrian crossing lights depicting haka and poi figure poses were installed," infusing Māori images into mainstream everyday activities such as crossing the street. At a ballet performance I attended, the barefoot dancers performed a variety of contemporary dances including one exploring Māori mythology, while another featured moving light designs while two dancers were physically connected through their clothing. During the Chinese New Year festivities in Wellington, a performance I watched focused on Westernised contemporary dance fused with traditional styles of the East. I attended a Passover Seder where the family had created their own Hagaddah, the Passover service booklet, which was continually updated so that it contained relevant information. They related historical events relating to the enslavement of the Jews along with current events including people around the world enduring war, starving as the result of famine, and the unfortunate events motivated by hatred that happened in Christchurch.

While learning about the Mataatua Wharenui of the Ngāti Awa people in the Bay of Plenty, I witnessed a light show documenting the story of local Māori and saw examples of wood carving from 1870 made using obsidian tools and others dating from 2000 that had been carved using contemporary metal chisels. The fact that so many marae around New Zealand are available for people to experience, engage with and learn about the customs, values and knowledge of local iwi is inspirational. Some marae are more traditional, while others are more contemporary, representing many iwi from around New Zealand in their carvings with the aim of being inclusive. They often depict modern images of historical events and stories, and host members of different iwi. I visited five marae where I learned more about Māori culture than I have experienced and learned about the Indigenous communities surrounding my home city.

Around Albuquerque, only the Acoma Pueblo allows tours of their 'Sky City' and when asked about different aspects of their culture, such as their religion, local tour guides say they cannot discuss it. My Indigenous students have mentioned the same thing when we are discussing their identities and I have learned not to ask questions, even though I am truly interested in learning about their customs, traditions, heritage and culture. I have observed the combination of historical and contemporary elements in Indigenous artwork, such as in Santa Domingo Pueblo Native American Ricardo Caté's cartoons that are published in the Santa Fe New Mexican newspaper in the "Without Reservations" section. The Indian Pueblo Cultural Center and National Hispanic Cultural Center in Albuquerque both exhibit artists and hold performances related to their cultural interests. Native American pueblos have feast days that include traditional dances, cultural activities, foods, and arts and crafts and are open to the public, but all of these events are not as visible as they are in New Zealand. Even two annual cultural events that are supported by the city are not well known to many locals, especially my students. These are the Marigold Day of the Dead parade that happens in Albuquerque at the beginning of November and the burning of the Zozobra, a large flammable marionette, marking the start of La Fiesta de Santa Fe, a celebration commemorating the defeat of the local Indigenous pueblos and Spanish resettlement of the city of Santa Fe.

Despite all the many cultural activities and programs that exist, the integration of Native American and Hispanic cultures is not particularly visible in the daily lives of locals living within Albuquerque. I feel I have to make a conscious effort to find and attend cultural events that happen around town. This is in stark contrast to the Māori culture that is more apparent in New Zealand.

From what I have observed, New Zealand is institutionally bicultural, not multicultural. The Treaty of Waitangi created 
a political agreement focusing on principles between the British and the Māori to establish a nation and build a government, ${ }^{12}$ creating the foundation for biculturalism that is especially evident in the education system. According to Michele Coxhead, teachers are including the Treaty principles of partnership, participation and protection into the classroom as they work together with Māori communities; protect Māori knowledge, values, interests and possessions; and emphasise Māori involvement at all levels of education. ${ }^{3}{ }^{2}$ Locals from all over New Zealand speak some words and phrases of Te Reo and students learn Te Reo and about Māori stories, dances, art and other culturally significant information in school.

The country's population is multicultural while the education system is bicultural. According to the 2013 census, 74 percent of the New Zealanders identify as European, 15 percent identify as Māori, 12 percent as Asian, 7 percent as Pasifika, and I percent as Middle Eastern, Latin American, or African, with the Asian, Middle Eastern, Latin American and African populations growing the fastest. ${ }^{14}$ When talking casually with art educators about students incorporating cultural aspects related to their heritage and family backgrounds into their artwork, I discovered that those students who have strong cultural and ethnic identities at home include them more often in their art. Formally, only Māori culture is included in the classroom, along with Western art techniques, making the education system bicultural.

The New Zealand Education Curriculum states that the "principle of cultural diversity calls for schools and teachers to affirm students' different cultural identities, and incorporate their cultural contexts into teaching and learning programmes."'I5 However, I found that cultures other than Māori and Pākehā were not addressed. I spoke informally about this with ten teachers both in primary and secondary schools, mostly in the North Island. Their responses to questions about including other cultures besides Māori and Pākehā ranged from not feeling comfortable teaching about cultures they did not know to not being required to teach anything but Māori culture so therefore they did not, even though their school was 39 percent Asian. One elementary school teacher adorned her classroom with Māori art only, while another taught children Māori designs. Two teachers said that because the students were raised in the New Zealand education system learning about Māori culture, that was also their culture and they did not need to incorporate those students' heritage or family backgrounds into their curriculum. Another teacher said she did not want to offend students by teaching cultures she was not familiar with, while another said she had never thought of incorporating the Asian and Filipino cultures of her students into her teaching.

These responses lead me to hypothesise that, unlike my university program in the US, university teacher preparation programs in New Zealand do not teach their graduates how to incorporate all students' cultural identities in the classroom. My teacher licensure program included a class devoted to multiculturalism in the art classroom, with material on how to respond to particular cultures. Only one art educator in my informal survey was concerned to incorporate all of his students' cultures by creating opportunities for students to focus on their connection to the land and their journey to where they were currently living. He spoke of giving the students the opportunity to research and figure out why particular things were important to them, such as hip hop. His students did not have to focus solely on Māori or Pākehā elements.

For the second part of my research, I formally interviewed six professional artists to learn what kind of support they had received on their pathway to become established, practicing artists. Two were Māori, one was Chinese and three were Pākehā.Their art fields consisted of special effects, body art, jade and bone carving, woodcarving, painting and street art. While pursuing their professions, they had enjoyed support from artists in their fields, whether this came from friends who taught them the medium or a teacher, mentor or tutor who helped guide them, especially at the beginning of their careers. The common factor I identified in their becoming artists was that they had all had a very positive, influential experience of art that sparked their interest in pursuing it throughout their lives. These experiences were very different, and included having an art specialist come into the classroom to conduct an art project; taking art classes in primary school or community college and loving them; having a mother who taught them a variety of art techniques and media after school; coming home to find a tattoo artist tattooing a family member's leg and being exposed to a variety of art books and magazines; and creating stickers, stencils, t-shirts, and graffiti art with friends on weekends. 
In order to find out how these artists retained and explored their culture in a commercial setting, I asked how they incorporated their heritage or family backgrounds into their artwork - something which they all felt they did. This element ranged from artwork being 'happy' as a way of escaping the harsh reality of life, and including traditional Chinese and Western elements in his paintings that reflected the cultural duality of growing up in Hong Kong; focusing on fantastical creatures after visiting a theme park in Europe and seeing the movie Labyrinth; and including in their artwork traditional and contemporary Māori elements that they had been exposed to throughout their lives. One artist felt that his life experience of working with a bulldozer and chainsaw had influenced his decision to become a sculptor, rather than his heritage or family background. When I asked if they felt their heritage and family backgrounds had influenced their decision to become artists, they either said that it had not or that it had guided them in making their decision, but was not the main reason they had chosen this profession.

When speaking with these artists about emerging artists, one Māori artist gave me a whole new perspective on the labels applied to artists and the Western perspective on pricing and selling art. He said that labeling people as emerging, professional or practicing artists is a Pākehā concept. Such labels manipulate a system that deals solely with financial control, and art produced for money is a colonising idea. He felt strongly that art should be used to develop the individual. I agree that art should help develop a person as a whole, but had never considered the Western concept of controlling the value of art in financial terms and labeling artists in this way. He explained that in the Māori world, art is created to make reference to, give respect for, and create records of the ancestors and to record human observation of the world, both past and present. It is a means of communication and an everyday practice. Art is gifted, rather than bought and sold, and it involves a reciprocation process, which can be activated years later. He feels that he straddles the two worlds of the koha system and the pricing of paintings to sell. The notions of pricing and selling art versus gifting it, as well as it being a means to explore one's identity, will fuel conversations I will have with my students.

Within my classroom, I plan to change my lessons so that they focus on storytelling. I will still teach a variety of art mediums and techniques, but will focus on the story lines within the work. More narratives from the cultures of my students will be included to help inspire them to collect and record their own stories. Including different cultural symbols and designs to represent flora and fauna in the students' artwork, for example, can enhance the storytelling elements. Traditional Chinese art always includes a word or phrase explaining the message underlying the artwork, so if there are Chinese students in the classroom, this aspect can be incorporated. If a culture has a name for a specific concept we are discussing, I will include that word in the art language as a way of promoting different home languages and sparking an interest in students learning the languages specific to their cultures. Another way of including students' languages, making them feel welcome and accepted, and raising awareness of all the different cultures in the classroom is simply to say 'hello' in the home languages of the students.

In order to expose students to a variety of art fields, I intend to bring more artists into the classroom to speak with the students about the narrative elements in their art and how their culture is expressed in their work. This will help students learn different methods of expressing their stories, culture, heritage and family backgrounds through creative processes. Hopefully, these guest artists will become part of an artist registry I am planning to create for students interested in pursuing art-related careers to access. Ideally, a paid internship or mentorship program would be set up for the artists and students involved. This scheme will take a while to establish, but will hopefully be completed in the near future.

Conducting art education research was a valuable professional development experience. Learning the importance of storytelling and communal discussions, and how some New Zealand artists include their heritage and family backgrounds in their artwork will change the way I structure my classes to engage my multicultural students. I yearn for my students to embrace their cultures, integrate them into their artwork, increase their cultural competence, and become prolific artists in their communities. 
Courtnee Bennett is a secondary-school art educator from Albuquerque, New Mexico, where she has lived for the past ten years. She recently completed the Fulbright Distinguished Awards in Teaching program in New Zealand and is a National Board Certified Teacher in the area of early adolescence through young adulthood (ages I I-18+). She is a graduate of the University of Cincinnati, receiving a Master of Fine Arts in 2D design and a Master of Arts in art education in 2009. Her Bachelor of Arts in earth and planetary sciences is from Washington University in St. Louis.

I David Bell, "Visual Arts Education in New Zealand: Curriculum, Promise and Challenge," Curriculum Matters, 6 (20 I0), $28-47$.

2 Jay P Greene, Brian Kisida, Cari A Bogulski, Anne Kraybill, Collin Hitt and Daniel H Bowen, "Arts Education Matters:We Know, We Measured it," Education Week, 2 I February 2019, https://www.edweek.org/ew/articles/20 14//2/03// 3greene.h34.html.

3 Bell, "Visual Arts Education in New Zealand;" Peter Smith, The History of American Art Education: Learning about Art in American Schools (Westport, CT: Greenwood Press, 1996).

4 Bell, "Visual Arts Education in New Zealand."

5 "Cultural Diversity," The New Zealand Curriculum Online, updated 26 March 2019, https://nzcurriculum.tki.org.nz/Principles/ Cultural-diversity (accessed 16 July 2019).

6 Peter Smith, The History of American Art Education: Learning about Art in American Schools (Westport, CT: Greenwood Press, 1996).

7 GreatSchools Staff, "What Every Parent Should Know about Their School Board," 17 April 2019, https://www.greatschools. org/gk/articles/school-board-candidates/ (accessed 16 July 2019).

8 Manzano High School, "High School Profile 20 I 8-2019," https://mhs-aps-nm.schoolloop.com/file/I 5227409 I I 950/I 407। 078 7326 I/2088673109347836324.pdf?filename=School Profile 2018-2019.pdf (accessed 16 July 20 I9).

9 Institute for Education Sciences, "Characteristics of Public Elementary and Secondary School Teachers in the United States: Results From the 2015-16 National Teacher and Principal Survey," https://nces.ed.gov/pubs2017/20 I 7072rev.pdf.

10 jill Smith, “'White Teachers/ Diverse Classrooms:' Looking Forward in Visual Arts Education in Auckland Secondary Schools," Aotearoa New Zealand Association of Art Educators, http://www.anzaae20 I7.co.nz/uploads/|/8/I/3/|8|39||5/jill_smith_-_ white_teachers-diverse_classrooms.pdf.

I I Felix Desmarais, "Wellington Crossing Lights Changed to Kapa Haka Figures to Honour Te Matatini Festival," Stuff, 2 I February 2019, https://www.stuff.co.nz/dominion-post/capital-life/capital-day/l I 072374 I/crossing-light-change-all-go-duringte-matatini (accessed 16 July 2019).

12 “'The Treaty in Brief," New Zealand History, https://nzhistory.govt.nz/politics/treaty/the-treaty-in-brief (accessed I6 July 20 I9).

13 Anna Clements, "Te Tiriti o Waitangi - Living the Values," School News, I November 2016, https://www.schoolnews. co.nz/2016/1 I/te-tiriti-o-waitangi-living-the-values/ (accessed 16 July 2019).

14 “Major Ethnic Groups in New Zealand," Stats NZ, 29 January 2015, https://www.stats.govt.nz/infographics/major-ethnicgroups-in-new-zealand (accessed 16 July 2019).

15 "Cultural Diversity," The New Zealand Curriculum Online. 